\title{
New species of dinoflagellate cysts from Maastrichtian-Danian chalks of the Danish North Sea
}

\author{
POUL SCHIOLER \\ Geological Survey of Denmark \\ Thoravej 8, DK 2400 \\ Copenhagen, Denmark.
}

\begin{abstract}
A palynological study of Danian - Maastrichtian chalks from the Dan oilfield (Danish North Sea) has revealed the presence of nine new species and subspecies of dinoflagellate cysts: Achomosphaera antleriformis sp. nov., Cassiculosphaeridia? tocheri sp. nov., Chlamydophorella? multifibrata sp. nov., Isabelidinium majae sp. nov., Hystrichosphaeropsis perforata sp. nov., Hystrichostrogylon borisii $\mathrm{sp}$. nov., Leberidocysta? flagellichnia sp. nov., Spiniferites foveolatus sp. nov. and Spiniferites pseudofurcatus granulosus ssp. nov. Seven of the taxa are considered important biostratigraphic markers in the area. J. Micropalaeontol., 12 (1): 99-112, August 1993.
\end{abstract}

\section{INTRODUCTION}

The Geological Survey of Denmark is, in cooperation with Maersk Olie og Gas AS, carrying out a multidisciplinary geological research project (the Dan Field Project), on improved mapping and characterization of chalk reservoirs and seal properties in the Dan oilfield in the North Sea. The Dan Field produces oil from Maastrichtian and Danian chalks, which form part of the Chalk Group (Deegan and Scull, 1977). An overview of the exploration and production geology of the Danish chalk play is presented in Andersen and Doyle (1990). The structure, stratigraphy and development history of the Dan Field is treated comprehensively in Jorgensen (1993). The Dan Field Project integrates seismic forward modelling and interpretation with sedimentology and biostratigraphy. The project includes the establishment of a high resolution bio-stratigraphical zonation in the reservoir chalks, based on dinoflagellate cysts (Schiøler and Wilson, 1992, 1993). During the study several previously undescribed dinoflagellate taxa were encountered, nine of which are described here.

\section{MATERIALS AND METHODS}

The dinoflagellate cysts were recovered from core samples from the following six wells (well name is followed by platform coordinates): M-1x (UTM 31 E $634889.8 m$ N 6149249.0m), ME-6 (UTM 31 E 633833.0m N 6150532.5m), MFA-4 (UTM 31 E 633336.9m N 6150421.0m), MFB-7 (UTM 31 E 633273.9m N 6150312.0m), M-9x (UTM 31 E 633502.4m N $6146726.0 \mathrm{~m}$ ) and M-10x (UTM 31 E $631842.0 \mathrm{~N} 6149710.5 \mathrm{~m}$ ). The locations of the wells are shown in Fig. 1. The samples were prepared using normal initial procedures for palynological preparation of chalk samples (cf. Wilson, 1971), except for oil-bearing chalks, which were prepared according to the method described in Nørgaard et al. (1991). Hydrofluoric acid treatment followed the maceration tankmethod described by Poulsen et al. (1991). The material was sieved through $18 \mu \mathrm{m}$ filter cloth; oxidation with nitric acid as well as heavy liquid separation with $\mathrm{ZnCl}_{2}$ was carried out whenever needed. Treatment with potassium hydroxide was not undertaken as this preparation step may alterate the morphologic appearance of the peridinioid dino-flagellates

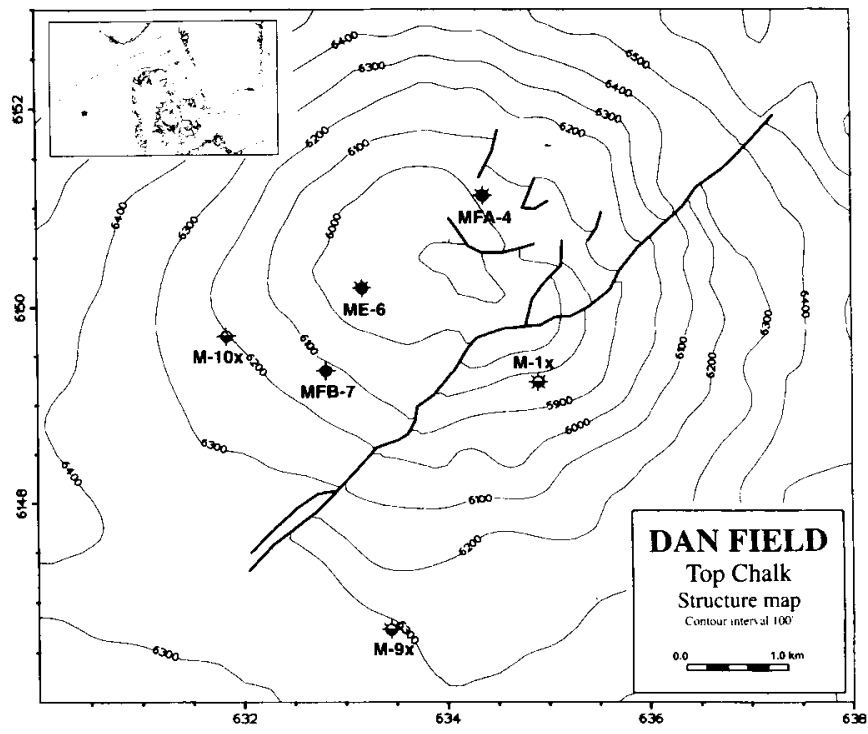

Fig. 1 Top Chalk Structure map of the Dan Field showing the locations of the wells studied herein.

(Schrank, 1988). The slides were mounted in glycerin jelly. Specimens were photographed with a Zeiss photomicroscope, located at the Institute of Geological and Nuclear Sciences, Lower Hutt, New Zealand.

The abundance of dinoflagellate cysts in the chalks is low, between 5 and 200 specimens per gram pure chalk. A higher abundance is found in stylolite-bearing chalks: 8 - 300 specimens per gram. Consequently stylolite-rich intervals were preferred during sampling of the cores. As the cysts are inert to most diagenetic processes, their relative enrichment in stylolites is thought to reflect concentration during the stylolite formation.

\section{BIOSTRATIGRAPHY OF THE WELLS}

The chalk intervals in the wells M-1x, M-9x, M-10x and MFA4 have previously been dated using calcareous microfossils (unpublished service company reports by: Bailey, 1980, 1983; Bailey and Jutson, 1983; Bagnall et al., 1971; Charnock et al., 1985). No biostratigraphical data are available from the wells 
ME- 6 and MFB-7. A synthesis of the biostratigraphy of M-1x, M-9x, M-10x and MFA-4, as well as a preliminary dating of ME-6 and MFB-7, based on dinoflagellate cysts, is outlined below.

Well M-1x (studied core interval: 1806.9m - 2003.8m)

Based on the influx of calcareous benthonic and planktonic foraminifera and the occurrence of Globigerina pseudobulloides and Gavelinella bullata, Bagnall et al. (1971) reported Danian strata in the interval $1798.3 \mathrm{~m}$ (core) - $1838.3 \mathrm{~m}$ (core). They dated the interval $1845.0 \mathrm{~m}-2066.6 \mathrm{~m}$ (core and cuttings) as Maastrichtian, based on the occurrence of Bolivinoides draco draco, Reussella cristata, Globotruncana contusa as well as the presence of other characteristic forms. The presence of $G$. contusa was held to suggest a relatively complete Maastrichtian succession, although the absence of the latest Maastrichtian species Pseudotextularia elegans was noted (Bagnall et al., 1971, p. 7). In-house information (Stouge, 1990) suggests that the boundary between the Late and Early Maastrichtian is positioned at $1928.5 \mathrm{~m}$, and that the stratigraphic interval down to $2003.8 \mathrm{~m}$ includes most of the Early Maastrichtian. The interval covered by the present study thus represents strata of Danian to Maastrichtian age, including at least some Early Maastrichtian.

Well M-9x (studied core interval: 1967.8m - 2060.8m)

Bailey (1980) reported the biostratigraphy of the well based on foraminifera: Globigerina daubjergensis, the Early Danian zonal marker of Bang (in Rasmussen, 1978), was encountered at $1972.4 \mathrm{~m}$ (side wall core). The Maas-trichtian/Danian boundary was placed between $1996.8 \mathrm{~m}$ (core) and $1998.0 \mathrm{~m}$ (core), based on the first downhole appearance of the planctonic foraminiferid association of Globotruncana contusa, Pseudotextularia elegans and Racemiguembelina fructicosa. The boundary between the latest and early Late Maastrichtian was placed between $2018.7 \mathrm{~m}$ (side wall cone) and $2021.5 \mathrm{~m}$ (side wall core), based on the lowest in situ occurrence of Pseudotextularia elegans at $2018.7 \mathrm{~m}$ associated with the highest occurrence of Neoflabellina reticulata at $2021.5 \mathrm{~m}$, following the zonation of Koch (1977). The boundary between the Early and Late Maastrichtian was, with some reservation, positioned at $2063.5 \mathrm{~m}$ (cuttings), based on the common downhole occurrence of Stensioeina pommerana from this depth and following Koch (1977) (in Bailey, 1980). The interval studied in the present paper thus ranges from the Late Danian to approximately 9 feet above the boundary between the Late and Early Maastrichtian.
Well M-10x (studied core interval: 1944.6m - 2029.4m) Bailey and Jutson (1983) examined two core samples just below the contact between the Palaeocene clay and the underlying Chalk Group, and encountered nannofossils indicating the Subzone D10 of Perch-Nielsen (1979) at the depth 1932.26m. Bailey (1983) examined 12 core samples from the depth interval $1956.8 \mathrm{~m}-1990.4 \mathrm{~m}$, and dated the interval $1956.8 \mathrm{~m}$ $1962.9 \mathrm{~m}$ as Danian, based on the total range of Globorotalia pseudobulloides and other significant taxa. The interval 1966.0m - 1984.3m represents the Late Maastrichtian based on the occurrence of Pseudotextularia elegans. The interval $1987.3 m-1990.4 m$ was, with some reservation, dated as Early Maastrichtian based on the common occurrence of calcisphaeres in the sample at $1987.3 \mathrm{~m}$. Four core samples from around the $\mathrm{K} / \mathrm{T}$ boundary $(1962.17 \mathrm{~m}-1963.84 \mathrm{~m})$ were investigated for calcareous microfossils by Charnock et al. (1985). The results show that an unconformity probably occurs between the Early Palaeocene and the latest Maastrichtian in the well (Charnock et al., 1985). The interval below $1990.4 \mathrm{~m}$ has not been investigated for calcareous microfossils. In summary the interval studied herein spans the Danian and Late Maastrichtian, and probably Early Maastrichtian.

Well MFA-4 (studied core interval: $2366.2 \mathrm{~m}-2414.7 \mathrm{~m}$ )

Charnock et al. (1985) investigated core samples from the interval $2366.2 \mathrm{~m}-2408.3 \mathrm{~m}$. The interval $2366.2 \mathrm{~m}-2400.0$ is dated as Early Palaeocene based on the presence of several calcareous nannofossil and foraminiferal taxa; the presence of specimens of Globotruncana contusa, although questionable to the authors, provides some evidence for the presence of uppermost Maastrichtian strata from $2402.7 \mathrm{~m}$ (Charnock et al., 1985). Age diagnostic foraminifera were not recovered from deeper samples. Based on the occurrence of large Arkhangelskiella cymbiformis down to $2408.3 \mathrm{~m}$, uppermost Maastrichtian strata are indicated at least to this level (Charnock et al., 1985). The interval studied herein thus covers the Early Palaeocene to at least the latest Maastrichtian. Wells ME-6 and MFB-7 (studied core intervals: ME-6: 2073.9m - 2083.6m, MFB-7: 2246.7m - 2436.9m)

The studied sequences from these wells have been correlated with the four other wells and with chronostratigraphical units by the present author using dinoflagellate cysts. Only two samples yielded dinoflagellate cysts in well ME-6. Both contain abundant Palynodinium grallator, and consequently belong to the Palynodinium grallator Zone of Hansen (1977),

\section{Explanation of Plate 1.}

Dinoflagellate cysts from the Dan Field, Danish North Sea. All figures to scale. Scale bar $=20 \mu \mathrm{m}$.

Fig. 1 Isabelidinium majae sp. nov. DGU Cat. no. 1992-PS-1. Holotype. Ventral surface up, sectional focus

Fig. 2 Isabelidinium majae sp. nov. DGU Cat. no. 1992-PS-2. Paratype. Dorsal surface up, sectional focus.

Fig. 3 Isabelidinium majae sp. nov. DGU Cat. no. 1992-PS-3. Paratype. Dorsal surface up, sectional focus.

Fig. 4 Isabelidinium majae sp. nov. DGU Cat. no. 1992-PS-4. Paratype. Ventral surface up, low focus.

Fig. 5 Isabelidinium majae sp. nov. DGU Cat. no. 1992-PS-5. Paratype. Ventral surface up, sectional focus. Specimen with folded periphragm.

Fig. 6 Isabelidinium majae sp. nov. DGU Cat. no. 1992-PS-6. Paratype. Ventral surface up, sectional focus.

Fig. 7 Hystrichostrogylon borisii sp. nov. DGU Cat. no. 1992-PS-7. Holotype. Lateral view, sectional focus.

Fig. 8 Hystrichostrogylon borisii sp. nov. DGU Cat. no. 1992-PS-8. Paratype. Dorsal surface up, sectional focus.

Fig. 9 Hystrichostrogylon borisii sp. nov. DGU Cat. no. 1992-PS-9. Paratype. Lateral view, sectional focus. 

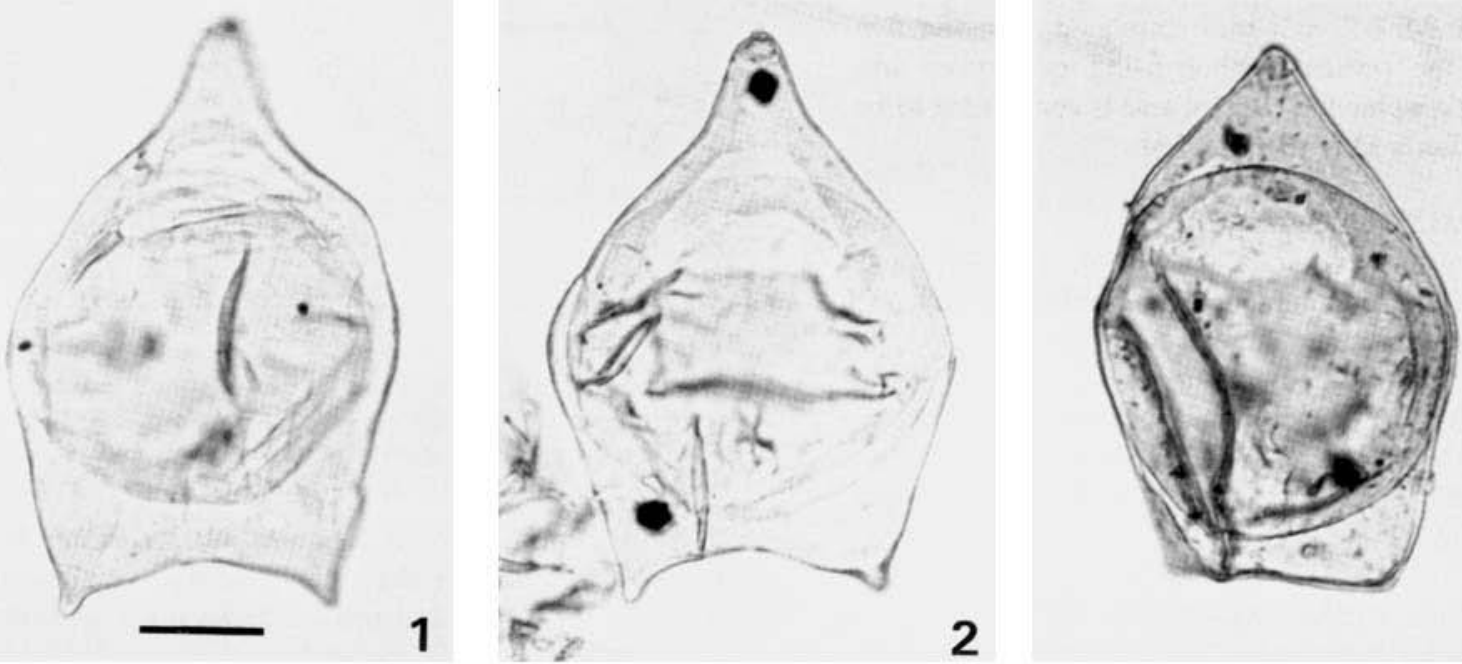

2

3

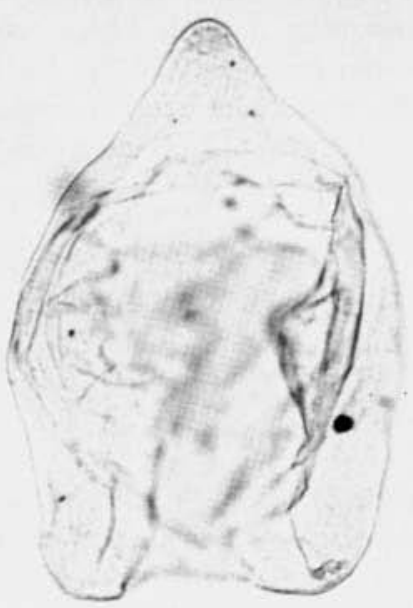

4

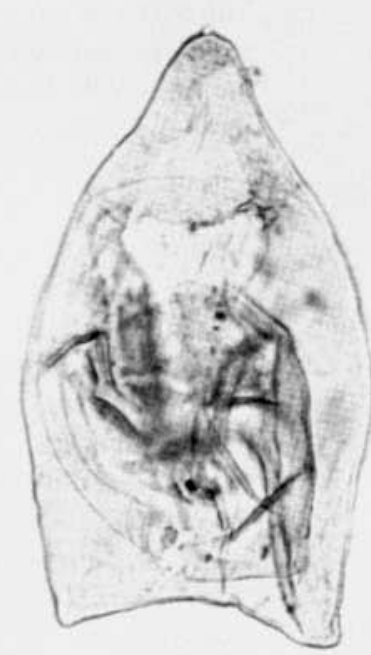

5
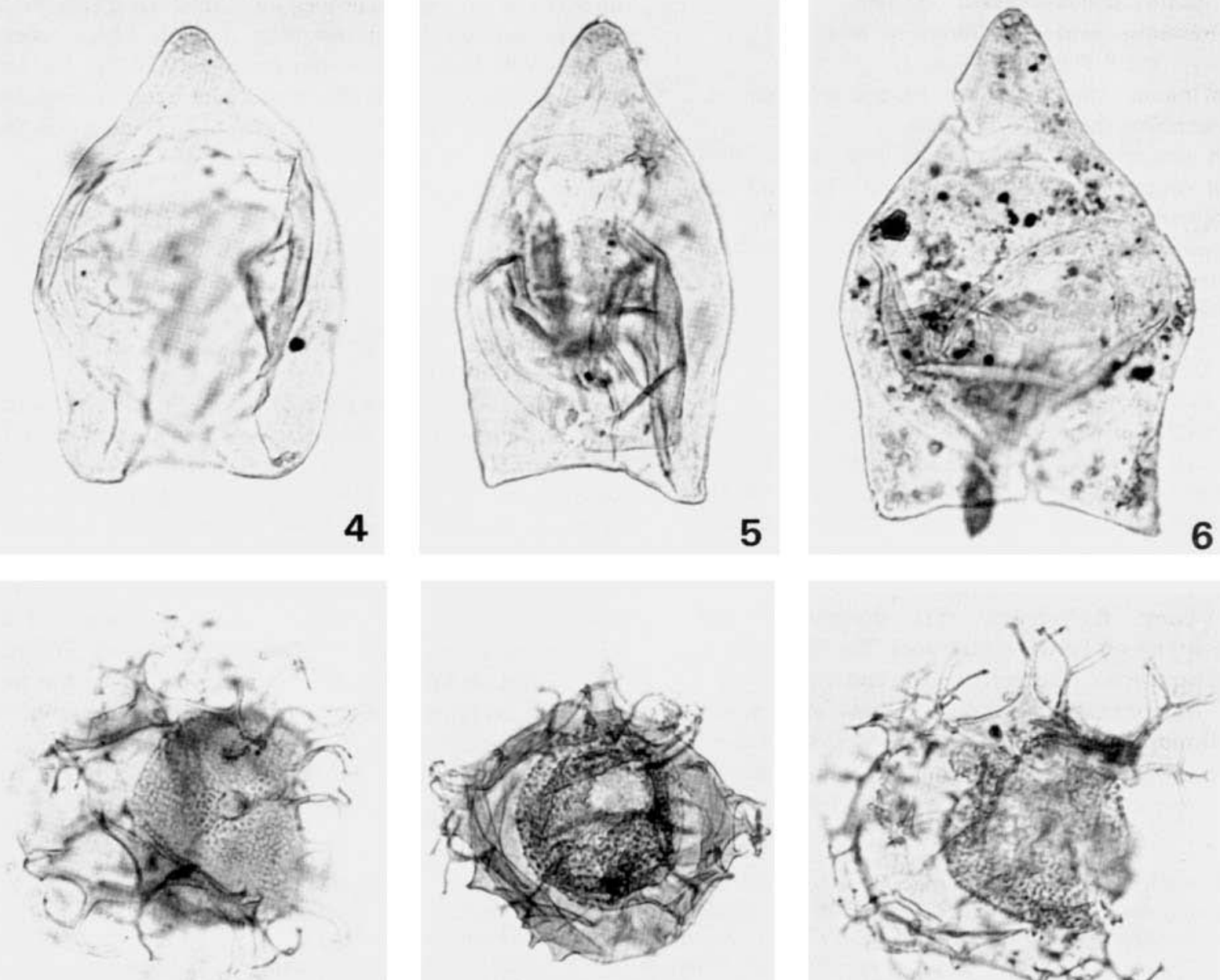

7

8

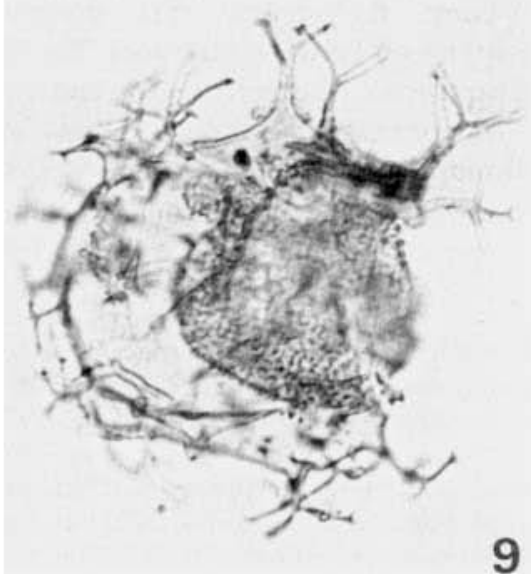


representing the latest Maastrichtian in Denmark. The studied interval from the MFB-7 well was correlated with the five other wells by the present author using qualitative and quantitative stratigraphic techniques, and is considered to be of Danian to late Early Maastrichtian age.

\section{SYSTEMATIC PALYNOLOGY}

Dinoflagellate cyst taxa described prior to 1989 and mentioned below are fully referenced in Lentin and Williams (1989). All other taxa are referenced herein. All type specimens and other figured specimens are lodged in the palynological collection of the Geological Survey of Denmark (DGU), and have been assigned DGU catalogue numbers. The inferred chronostratigraphical distribution of the new taxa is summarized in Fig. 2.

\section{Division Pyrrhophyta Pascher, 1914 \\ Class Dinophyceae Fritsch, 1929 \\ Order Peridiniales Haeckel, 1894 \\ Genus Achomosphaera Evitt 1963 \\ Achomosphaera antleriformis sp. nov.}

(Pl. 3, Figs 1-6, text-fig. 2)

Derivation of name. After the robust process terminations, sometimes resembling the antlers of a deer.

Diagnosis. A skolochorate gonyaulacoid cyst which lacks indications of sutures between the processes. The processes are gonal, long-stemmed and straight, with wide, robust bi- or trifurcations which give rise to secondary furcations that are truncated terminally.

Holotype. DGU Cat. no. 1992-PS-19 (Pl. 3, fig. 2, text-fig. 2a,b). Well M-1x, depth 1936.1m, Dan Field, Danish North Sea.

Paratype. DGU Cat. No. 1992-PS-18 (Pl. 3, figs 1,4)

DGU Cat. No. 1992-PS-20 (Pl. 3, fig. 3)

DGU Cat. No. 1992-PS-21 (Pl. 3, fig. 5)

Stratigraphic occurrence: ME-6: $2082.1 \mathrm{~m}$ - 2083.6m, MFA-4: 2404.0m - 2414.7m, MFB-7: 2281.5m - 2436.9m, M-1x: 1846.5m - 2003.8m, M-9x: 2001.6m - 2060.8m, M-10x: 1964.8m 2029.4m. Maastrichtian in the Dan Field, Danish North Sea. Common.

Description. Large skolochorate cyst. Periphragm and endophragm appressed between processes. The cyst body is ovoidal to subspherical. The periphragm and endophragm are smooth. The processes are gonal, hollow and closed; process length approximately equals the endocystal radius. The processes have slender stems that expand distally in

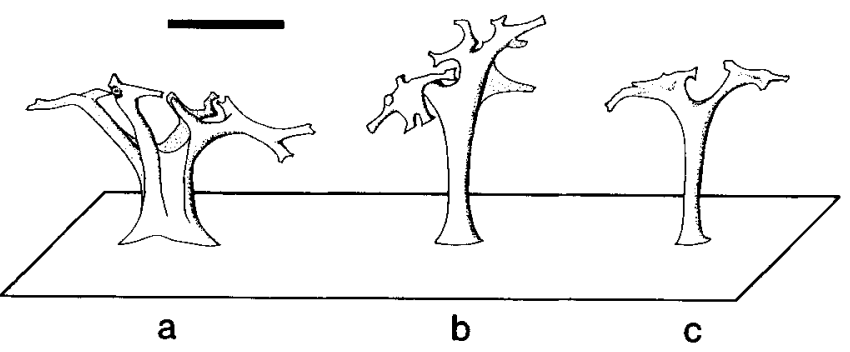

Fig. 2 Camera lucida drawings of process types of Achomosphaera antleriformis sp. nov. a) DGU Cat. no. 1992-PS-19, holotype. Apical process complex. b) Same specimen, paracingular process, jointed. c) DGU Cat. no. 1992-PS-22. Hypocystal process, jointed. Scale bar $=20 \mu \mathrm{m}$.

broad primary trifurcations followed by secondary bi- or trifurcations, resembling the antlers of a deer. Text-fig. 2 shows a selection of typical process types on $A$. antleriformis $\mathrm{sp}$. nov. The width of the process terminations of the largest processes approximately equals the radius of the endocyst. The stems of the apical processes are sometimes connected by septa of variable height, forming a single polar process complex with four trifurcate terminations (Pl. 3, figs 2,5, textfig. 3a). Archaeopyle type $\mathrm{P}(3)$, operculum free. Paracingulum and parasulcus not visible. Paratabulation gonyaulacoid, suggested by the position of the processes.

\begin{tabular}{|c|c|c|}
\hline Dimensions (in $\mu \mathrm{m}$ ): & holotype & range \\
\hline overall length & 107 & $101(111) 130$ \\
\hline overall width & 93 & $87(100) 110$ \\
\hline ength of endocyst & 61 & $58(61) \quad 78$ \\
\hline dth of endocyst & 49 & $44(54) \quad 78$ \\
\hline cess len & $23-29$ & $20-32$ \\
\hline
\end{tabular}

\section{Specimens measured. 7}

Remarks. Achomosphaera antleriformis sp. nov. is separated from the subspecies of Achomosphaera ramulifera (Deflandre 1937) Evitt 1963 by its more robust and truncated process terminations. A. antleriformis sp. nov. furthermore has narrower process stems than Achomosphaera ramulifera ramulifera (Deflandre 1937) Evitt 1963, and twice as long processes as Achomosphaera ramulifera gabonensis (Boltenhagen 1977) Lentin and Williams 1981. Achomosphaera ramulifera perforata (Davey and Williams 1966) Lentin \& Williams 1973 is separated from the new species by its fenestrate processes. Achomosphaera fenestrata Kirsch 1991 differs from the new species in having open processes with striate process stems and a perforated

\section{Explanation of Plate 2}

Dinoflagellate cysts from the Dan Field, Danish North Sea. Scale bars $=20 \mu \mathrm{m}$.

Fig. 1 Hystrichostrogylon borisii sp. nov. DGU Cat. no. 1992-PS-10. Lateral view, sectional focus.

Fig. 2 Hystrichostrogylon borisii sp. nov. DGU Cat. no. 1992-PS-11. Lateral view, sectional focus. Same scale as 1.

Fig. 3 Hystrichostrogylon borisii sp. nov. DGU Cat. no. 1992-PS-12. Paratype. Lateral view, sectional focus. Same scale as 1.

Fig. 4 Hystrichosphaeropsis perforata sp. nov. DGU Cat. no. 1992-PS-13. Holotype. Dorsolateral view, sectional focus.

Fig. 5 Hystrichosphaeropsis perforata sp. nov. DGU Cat. no. 1992-PS-14. Paratype. Dorsolateral view, sectional focus. Same scale as 4.

Fig. 6 Hystrichosphaeropsis perforata sp. nov. DGU Cat. no. 1992-PS-15. Paratype. Ventral surface up, sectional focus. Same scale as 4.

Fig. 7 Hystrichosphaeropsis perforata sp. nov. DGU Cat. no. 1992-PS-16. Ventral surface up, sectional focus.

Fig. 8 Hystrichosphaeropsis perforata sp. nov. DGU Cat. no. 1992-PS-17. Close-up of antapical part of pericyst. Notice coarse perforations of the free part of the periphragm. 

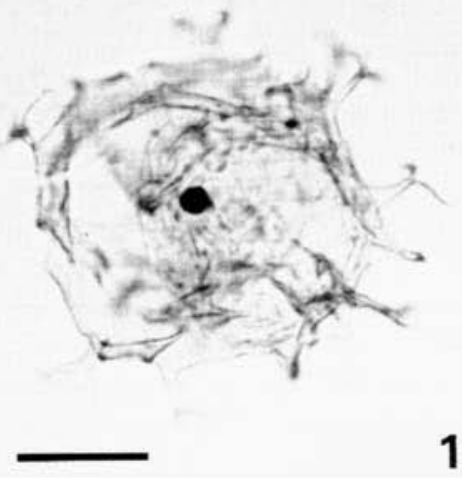
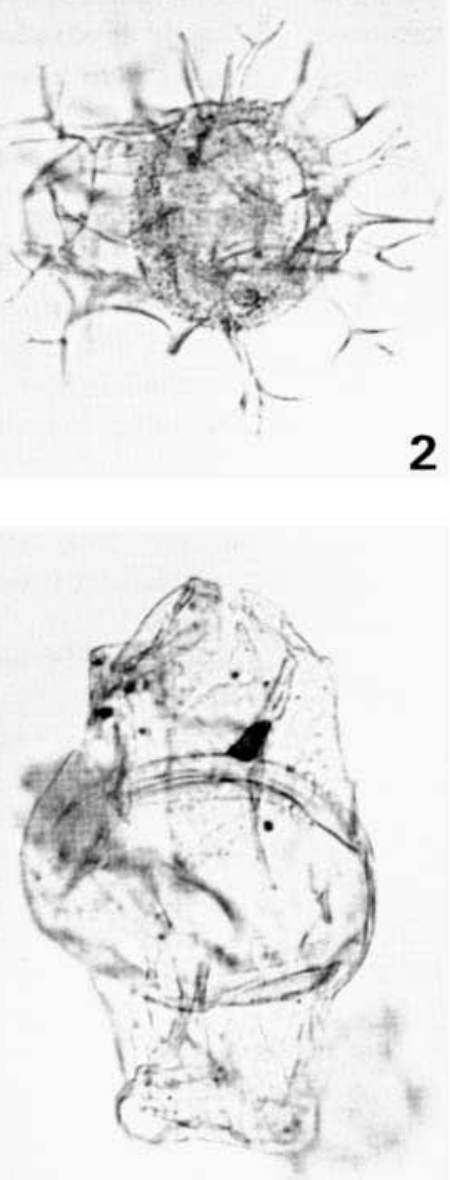

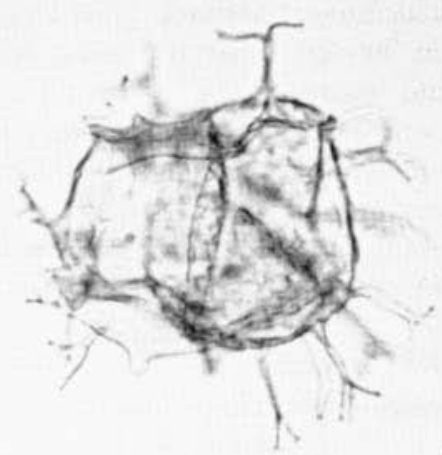

3

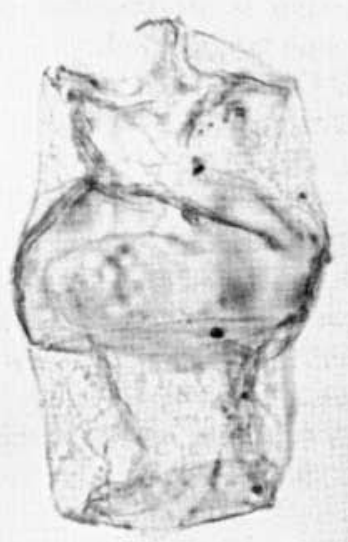

5

6

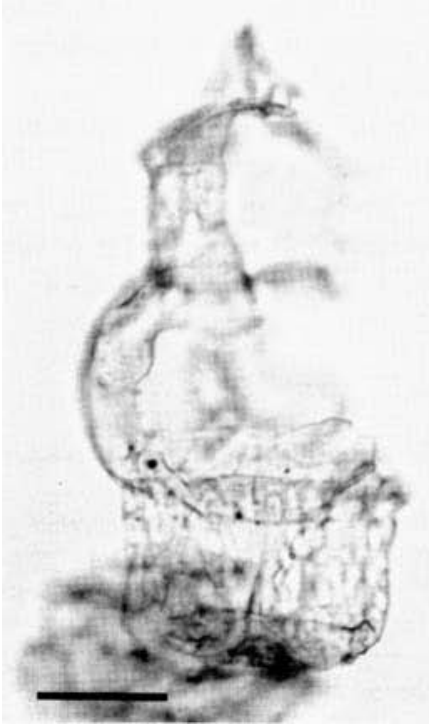

4

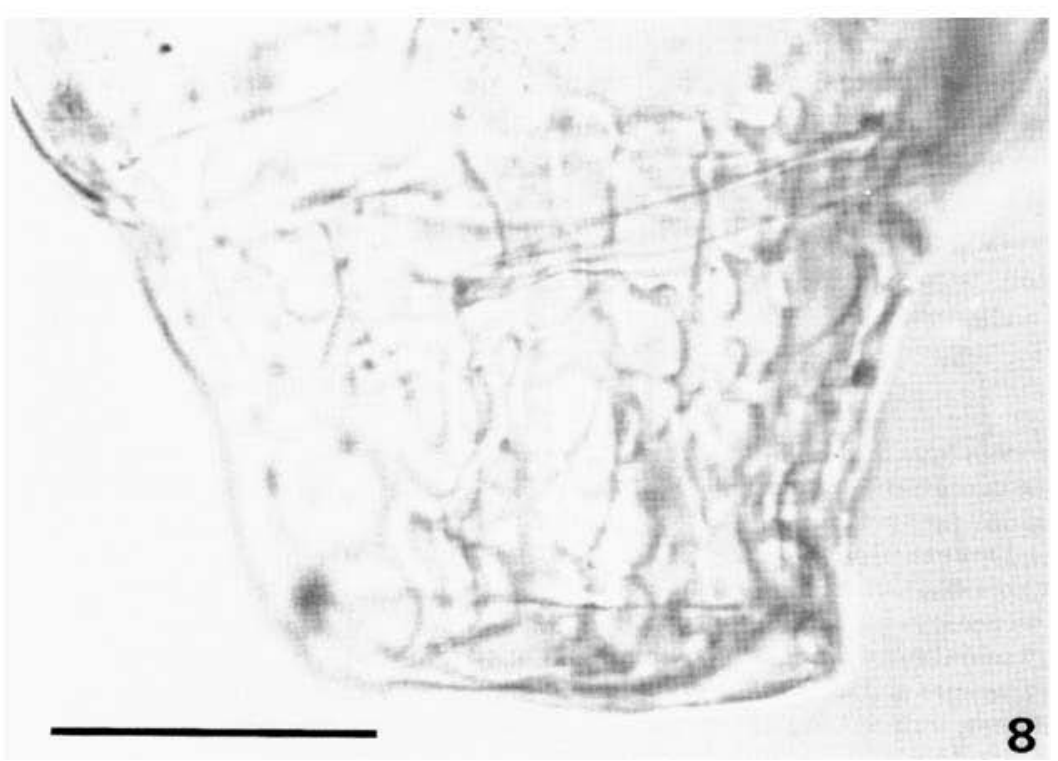


membrane connecting the distal furcations of each process. Achomosphaera alcicornu (Eisenack 1954) Davey \& Williams 1966 differs in having open processes which terminate trifurcating and funnel-shaped. Hansen (1977, fig. 17f) illustated a specimen of the latter species from the Danian of Denmark which has a superficial resemblance to the new species; his specimen can be differentiated by the lack of distinct branching of the process terminations and the presence of faint sutures between the process bases.

\section{Genus Cassiculosphaeridia Davey 1969 Cassiculosphaeridia? tocheri sp. nov.} (Pl. 4, Figs 4-12)

Derivation of name. In honour of the palynologist Dr. Bruce A. Tocher, University of Aberystwyth, who has worked extensively on Late Cretaceous dinoflagellate cysts. Diagnosis. A large spherical to subspherical autocyst in which the phragm is ornamented with a thick-walled reticulum enclosing large subspherical lumina.

Holotype. DGU Cat. no. 1992-PS-31 (Pl. 4, figs 4,5). Well M9x, depth 2031.2m, Dan Field, Danish North Sea.

Paratypes. DGU Cat. No. 1992-PS-32 (Pl. 4, fig. 6)

DGU Cat. No. 1992-PS-33 (Pl. 4, fig. 7)

DGU Cat. No. 1992-PS-37 (Pl. 4, fig. 11)

DGU Cat. no. 1992-PS-38 (Pl. 4, fig. 12)

Stratigraphic occurrence. ME-6: 2082.1m - 2083.6m, MFA-4: 2403.1m - 2414.7m, MFB-7: 2319.2m - 2394.8m. M-1x: $1846.5 \mathrm{~m}$ - 1869.1m, M-9x: 2001.6m - 2060.8m, M-10x: $1966.6 \mathrm{~m}$ - 2029.4m. Late Maastrichtian in the Dan Field, Danish North Sea. Frequent in some intervals, rare elsewhere.

Description. A spherical to subspherical autocyst. The autophragm is thick-walled and reticulate, enclosing large subspherical lumina which open to the exterior through irregular subcircular holes. The height of the reticulation and the size of the lumina may vary slightly from specimen to specimen but are approximately constant on a specimen. Height of reticulation and diameter of lumina: $6-12 \mu \mathrm{m}$. The archaeopyle is apical, type (tA), judged from its size and shape (Pl. 4, fig. 4), but is often absent or difficult to detect. Paracingulum and parasulcus are absent. Paratabulation is not indicated apart from inconsistent presence of archaeopyle.

\begin{tabular}{lccc} 
Dimensions (in $\mu \mathrm{m}):$ & holotype & \multicolumn{2}{c}{ range } \\
total diameter & 92 & $78(89)$ & 96 \\
height of ectophragm & 9 & $6(9)$ & 12
\end{tabular}

Specimens measured. 13

Remarks. As archaeopyle relationship is somewhat problematic in this species and paratabulation is absent, it is with some hesitation that the new taxon is established in Class Dinophyceae. Alternatively the taxon could be a spore, a pollen grain, or an acritarch; however, in all the Maastrichtian samples examined during the present study, spores and pollen as well as acritarchs are very rare. The occasional presence of features that point to an apical archaeopyle on the new species (see Pl. 4, figs 4,6,9,11), is currently taken as sufficient evidence by the present author for the location of the taxon in Class Dinophyceae. The new species differs from all other species of Cassiculosphaeridia in having a high and thick-walled reticulum.

\section{Genus Chlamydophorella Cookson and Eisenack 1958 emend. Duxbury 1983 \\ Chlamydophorella? multifibrata sp. nov.} (Pl. 5, Figs 7-12)

Derivation of name. After the numerous strands bearing the ectophragm.

Diagnosis. A subspherical differentiated autocyst with apical archaeopyle. The ectophragm is connected to the autocyst by a densely fibrous mat, formed by numerous hairlike strands.

Holotype. DGU Cat. no. 1992-PS-47 (Pl. 5, fig. 9). Well M-9x, depth 2001.6m, Dan Field, Danish North Sea.

Paratypes. DGU Cat. No. 1992-PS-45 (Pl. 5, fig. 7)

DGU Cat. No. 1992-PS-46 (Pl. 5, fig. 8)

DGU Cat. No. 1992-PS-48 (Pl. 5, fig. 10)

DGU Cat. no. 1992-PS-50 (Pl. 5, fig. 12)

Stratigraphic occurrence. MFA-4: $2403.1 \mathrm{~m}-2404.9 \mathrm{~m}$, MFB7: 2281.5m - 2429.6m, M-1x: 1846.5m - 1997.7m, M-9x: 2001.6m - 2050.1m, M-10x: 1964.8m - 2001.0m. Maastrichtian in the Dan Field, Danish North Sea. Frequent.

Description. A differentiated autocyst with a subcircular outline. The wall of the autophragm is thick, the ectophragm is very thin. The autophragm and the ectophragm are connected by a densely fibrous mat of very thin strands $(<0.25 \mu \mathrm{m}$ in thickness). Length of strands $4-11$

\section{Explanation of Plate 3.}

Dinoflagellate cysts from the Dan Field, Danish North Sea. Scale bars $=20 \mu \mathrm{m}$, except 14 .

Fig. 1 Achomosphaera antleriformis sp. nov. DGU Cat. no. 1992-PS-18. Paratype. Dorsolateral view, sectional focus. Artificially stained specimen. Fig. 2 Achomosphaera antleriformis sp. nov. Holotype. DGU Cat. no. 1992-PS-19. Ventrolateral view, sectional focus. Same scale as 1.

Fig. 3 Achomosphaera antleriformis sp. nov. DGU Cat. no. 1992-PS-20. Paratype. Lateral view, sectional focus. Fig. 4 Achomosphaera antleriformis sp. nov. DGU Cat. no. 1992-PS-18. Same specimen and scale as 1. High focus. Fig. 5 Achomosphaera antleriformis sp. nov. DGU Cat. no. 1992-PS-21. Paratype. Lateral view, sectional focus. Same scale as 1. Fig. 6 Achomosphaera antleriformis sp. nov. DGU Cat. no. 1992-PS-22. Lateral view, low focus. Same scale as 1. Fig. 7 Leberidocysta? flagellichnia sp. nov. DGU Cat. no. 1992-PS-23. Holotype. Ventral surface up, high focus. Fig. 8 Leberidocysta? flagellichnia sp. nov. Same specimen and scale as 7. Sectional focus. Fig. 9 Leberidocysta? flagellichnia sp. nov. DGU Cat. no. 1992-PS-24. Paratype. Ventral side up, high focus. Same scale as 7. Fig. 10 Leberidocysta? flagellichnia sp. nov. Same specimen as 9, same scale as 7. Sectional focus. Fig. 11 Leberidocysta? flagellichnia sp. nov. DGU Cat. no. 1992-PS-25. Paratype. Oblique ventrolateral view, high focus. Same scale as 7 . Fig. 12 Leberidocysta? flagellichnia sp. nov. DGU Cat. no. 1992-PS-26. Paratype. Ventral surface up, high focus. Same scale as 7 .

Fig. 13 Leberidocysta? flagellichnia sp. nov. DGU Cat. no. 1992-PS-27. Paratype. Ventral side up, high focus. Same scale as 7. Fig. 14 Leberidocysta? flagellichnia sp. nov. Same specimen as 13. Close-up of flagellar scar. Scale bar $=10 \mu \mathrm{m}$. 

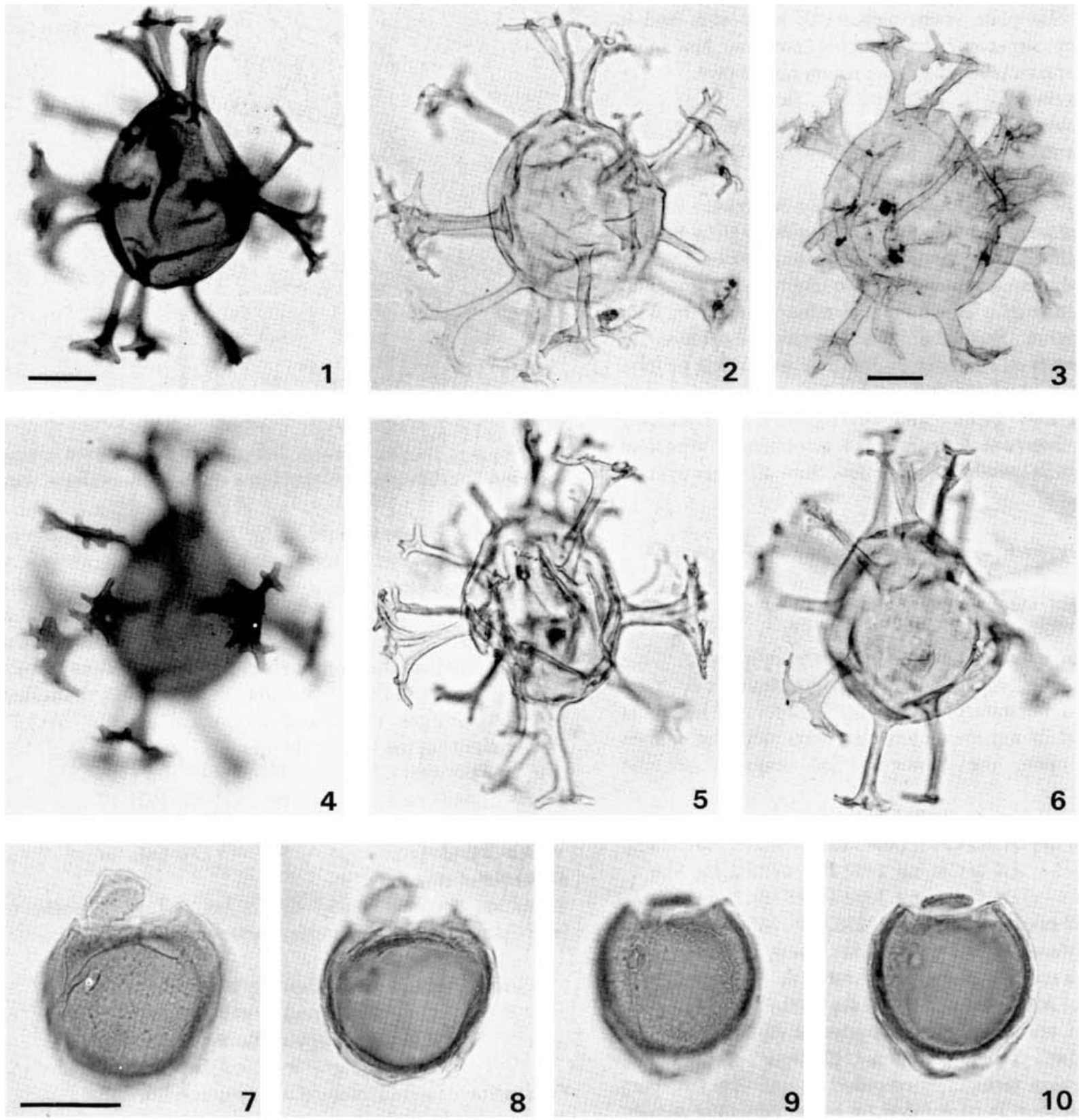

7

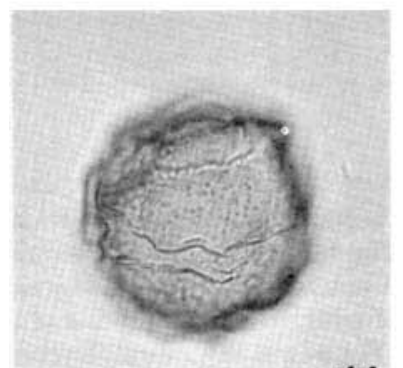

11
4
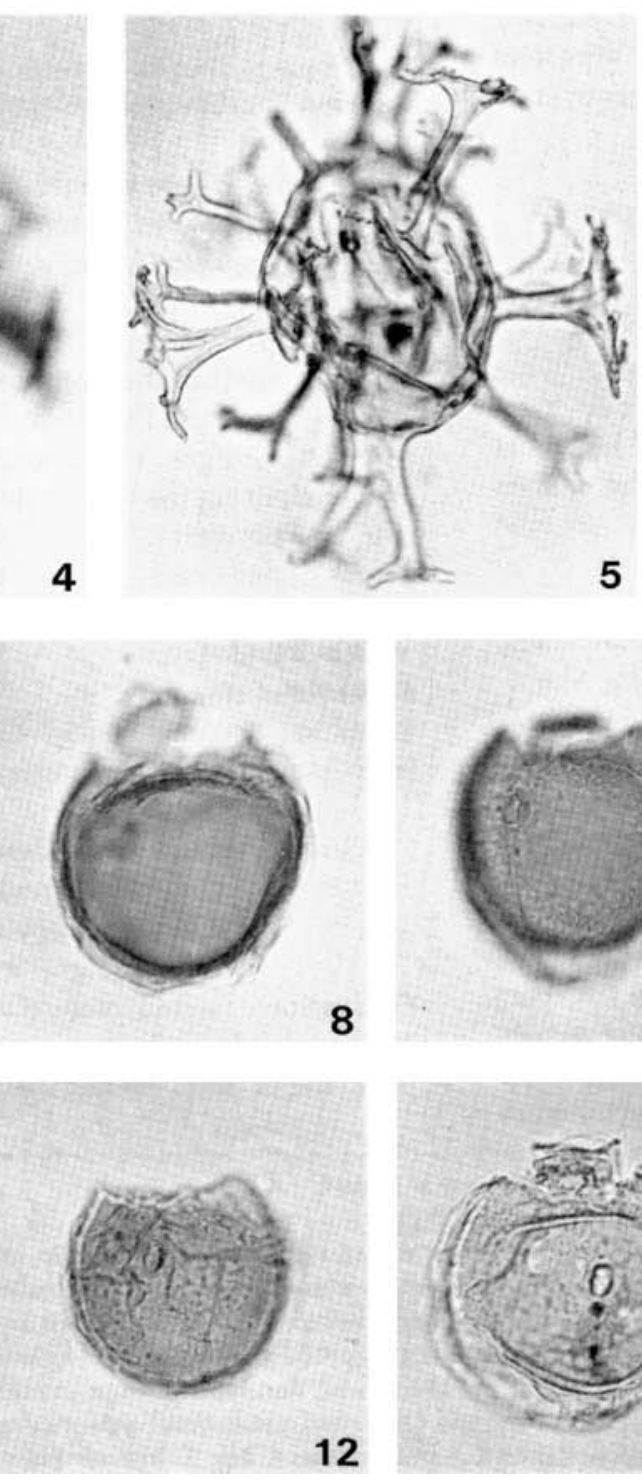

8

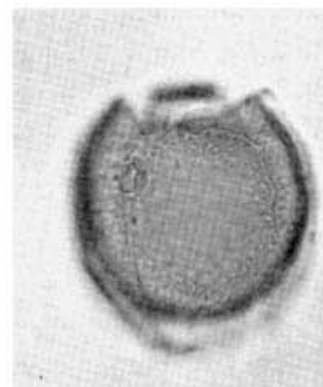

9

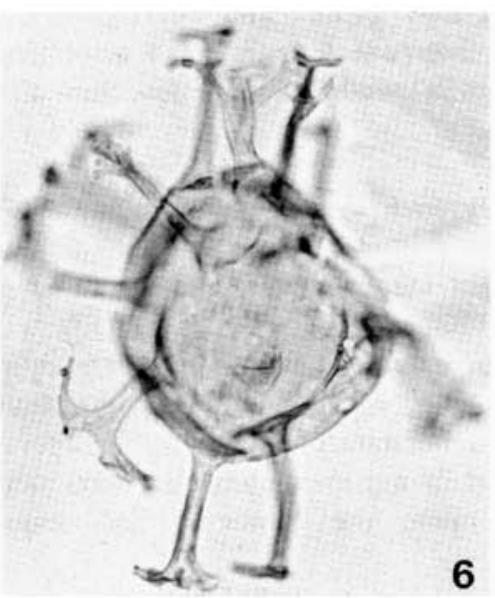

6
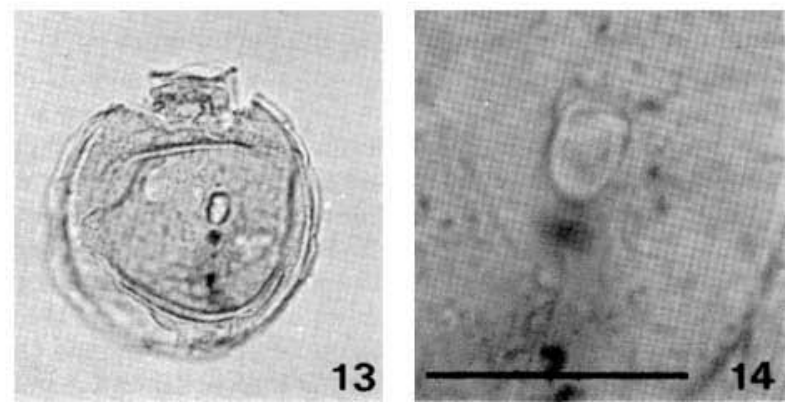
$\mu \mathrm{m}$. The archaeopyle is apical ( $\mathrm{tA}$ ), the operculum is free. The precingular plate series consists of six plates, and is expressed by accessory archaeopyle sutures. No other indications of paratabulation are present on the cyst.

\begin{tabular}{lccc} 
Dimensions (in $\mu \mathrm{m}$ ): & holotype & \multicolumn{2}{c}{ range } \\
overall diameter & 61 & $60(63) 70$ \\
length of fibrous strands & $6-8$ & 4 & $(7) 11$
\end{tabular}

Specimens measured. 12

Remarks. The new species superficially resembles species of Cometodinium Deflandre and Courtville 1939 in having numerous closely spaced processes, but differs in the development of an ectophragm enclosing the processes and in the presence of a conspicuous archaeopyle. It is with some hesitation that the new species is placed in Chlamydophorella as its lacks the bifid or expanded process terminations typical for that genus. The new species may belong to a new genus. The development of a densely fibrous mat between autocyst and ectophragm separates Chlamydophorella? multifibrata sp. nov. from all other species in the genus.

Genus Hystrichosphaeropsis Deflandre 1935 emend. Sarjeant 1982

Hystrichosphaeropsis perforata sp. nov.

(P1. 2, Figs 4-8, text-fig. 3)

Derivation of name. After the perforate periphragm.

Diagnosis. An elongate bicavate gonyaulacoid cyst with perforate to fenestrate periphragm. The epi- and hypocoel are large and of approximately the same size; the epicyst has acute apex, the hypocyst has rounded to flat termination.

Holotype. DGU Cat. no. 1992-PS-13 (Pl. 2, fig. 4, text-fig. 3). Well MFA-4, depth $2414.7 \mathrm{~m}$, Dan Field, Danish North Sea. Paratypes. DGU Cat. no. 1992-PS-14 (Pl. 2, fig. 5)

DGU Cat. no. 1992-PS-15 (Pl. 2, fig. 6)

Stratigraphic occurrence. MFA-4: $2353.7 \mathrm{~m}$, MFB-7: $2362.0 \mathrm{~m}$ : early Late Maastrichtian in the Dan Field, Danish North Sea. Rare in a narrow stratigraphic interval.

Description. An elongated bicavate cyst. The peri- and endophragm are smooth and appressed equatorially. The epiperiphragm tapers to a blunted horn. The hypoperiphragm terminates rounded to flat. The free part of the periphragm is perforated by large, generally axially elongated perforations $(3-10 \mu \mathrm{m})$. Sometimes the perforations are very closely spaced, giving the periphragm

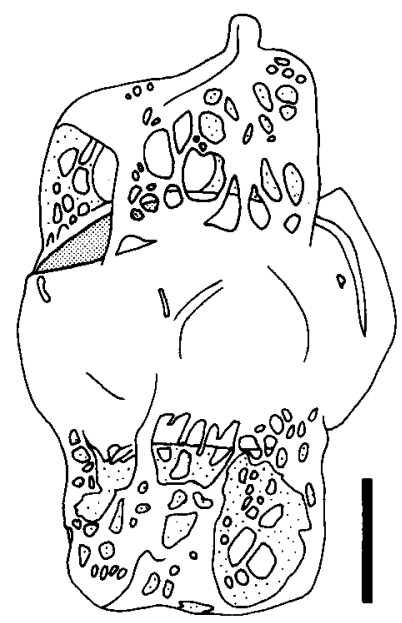

Fig. 3 Hystrichosphaeropsis perforata sp. nov. DGU Cat. no. 1992-PS-13. Camera lucida drawing of the dorsolateral surface of the holotype. Scale bar $=20 \mu \mathrm{m}$.

a fenestrate appearance (Pl. 2, fig. 8). The archaeopyle type is $P(3)$; the peri- and endoperculum are free. The position of the paracingulum is indicated by $4-5$ low and axially elongated protrosions of the periphragm (length of protrusions $c .3-5 \mu \mathrm{m}$ ). Three of the protrusions on the holotype are indicated on text-fig. 3 . The parasulcus is only faintly indicated. The paratabulation is partially indicated by folds or ridges on the periphragm: $4^{\prime}, 6^{\prime \prime}, ? \mathrm{c}, ? \mathrm{~s}, ? 6^{\prime \prime \prime}, ? \mathrm{p}, 1^{\prime \prime \prime \prime}$. Dimensions (in $\mu \mathrm{m}$ ): holotype range length of pericyst $\quad 96 \quad 87$ (97) 104 $\begin{array}{lllll}\text { width of pericyst } & 58 & 55 & (60) & 67\end{array}$ length of endocyst $\quad 38 \quad 35$ (41) 44 $\begin{array}{lllll}\text { width of endocyst } & 58 & 55 & (60) & 67\end{array}$

Specimens measured. 9

Remarks. The new species differs from all other species of Hystrichosphaeropsis in having a perforate periphragm.

Genus Hystrichostrogylon Agelopoulos 1964 emend. Stover and Evitt 1978

Hystrichostrogylon borisii sp. nov.

(Pl. 1, figs 7-9, Pl. 2, figs 1-3)

Derivation of name. Named after my son Boris.

Diagnosis. A camocavate gonyaulacoid cyst in which the periphragm and endophragm are appressed on the dorsal

\section{Explanation of Plate 4}

Dinoflagellate cysts from the Dan Field, Danish North Sea. Scale bars $=20 \mu \mathrm{m}$.

Fig. 1 Spiniferites pseudofurcatus granulosus ssp. nov. DGU Cat. no. 1992-PS-28. Paratype. Ventral surface up, low focus. Fig. 2 Spiniferites pseudofurcatus granulosus ssp. nov. DGU Cat. no. 1992-PS-29. Holotype. Oblique apical view, high focus. Same scale as 1. Fig. 3 Spiniferites pseudofurcatus granulosus ssp. nov. DGU Cat. no. 1992-PS-30. Paratype. Ventral surface up, sectional focus. Same scale as 1. Fig. 4 Cassiculosphaeridia? tocheri sp. nov. DGU Cat. no. 1992-PS-31. Holotype. Antapical surface up, low focus. Fig. 5 Cassiculosphaeridia? tocheri sp. nov. Same specimen and scale as 4. High focus. Fig. 6 Cassiculosphaeridia? tocheri sp. nov. DGU Cat. no. 1992-PS-32. Paratype. Oblique lateral view, high focus. Same scale as 4. Fig. 7 Cassiculosphaeridia? tocheri sp. nov. DGU Cat. no. 1992-PS-33. Paratype. Unknown orientation. Same scale as 4. Fig. 8 Cassiculosphaeridia? tocheri sp. nov. DGU Cat. no. 1992-PS-34. Oblique lateral view, sectional view. Same scale as 4. Fig. 9 Cassiculosphaeridia? tocheri sp. nov. DGU Cat. no. 1992-PS-35. Operculum. Same scale as 4. Fig. 10 Cassiculosphaeridia? tocheri sp. nov. DGU Cat. no. 1992-PS-36. Lateral view, high focus. Same scale as 4. Fig. 11 Cassiculosphaeridia? tocheri sp. nov. DGU Cat. no. 1992-PS-37. Paratype. Oblique lateral view, high focus. Same scale as 4 . Fig. 12 Cassiculosphaeridia? tocheri sp. nov. DGU Cat. no. 1992-PS-38. Paratype. Unknown orientation. Same scale as 4. 

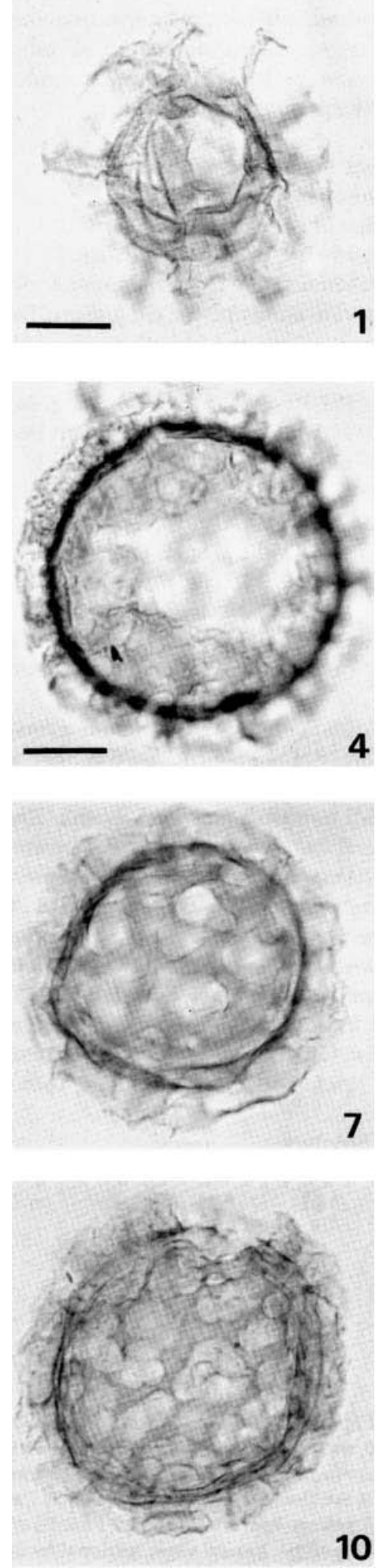
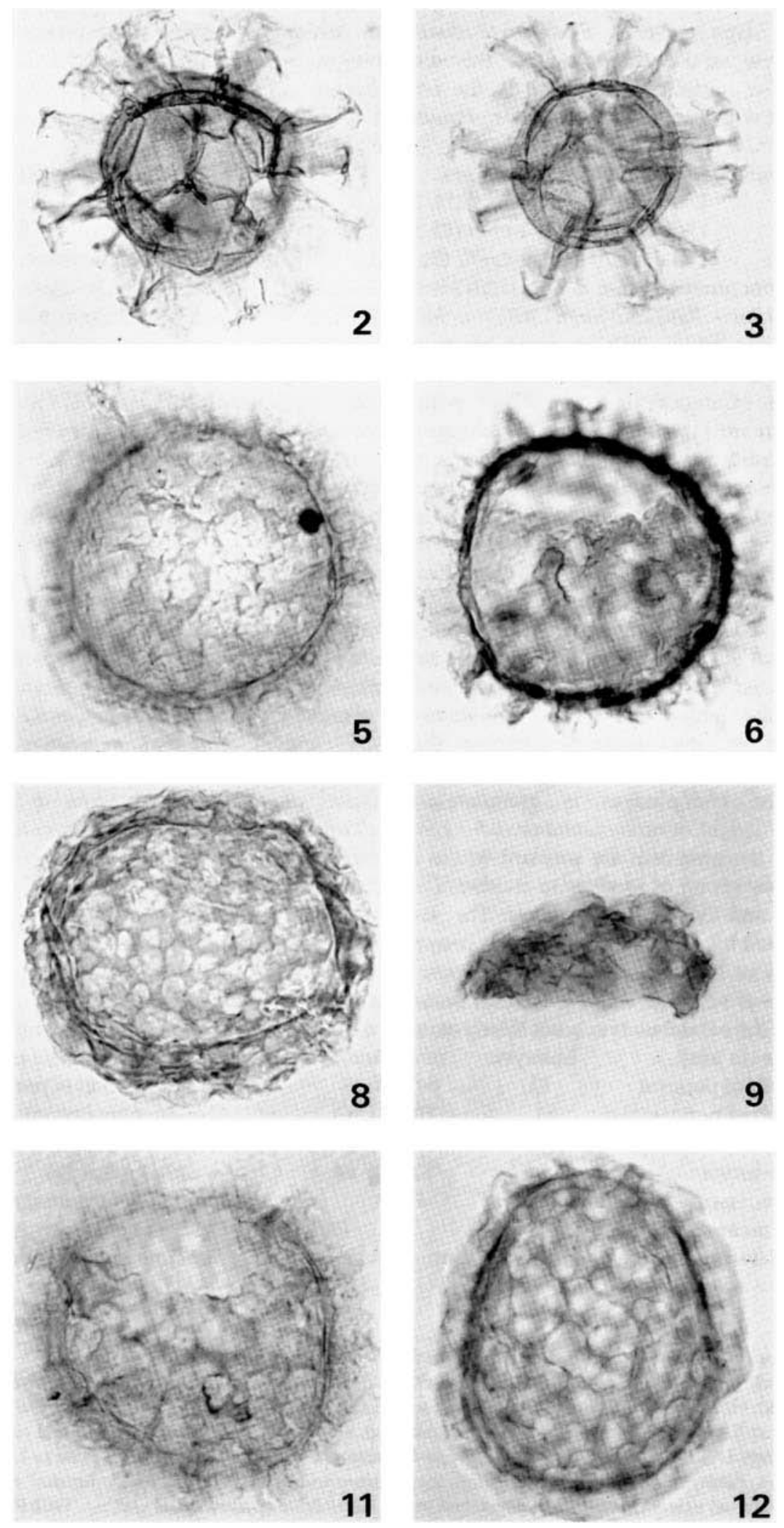
hemisphere. The ventral pericoel opens to the exterior through a large rounded midventral claustrum which approximately equals the radius of the endophragm in diameter. The periphragm is smooth, the endophragm is ornamented with granulae, verrucae or vermiculae.

Holotype. DGU Cat. no. 1992-PS-7 (P1. 1, fig. 7). Well M-10x, depth 1966.6m, Dan Field, Danish North Sea.

Paratypes. DGU Cat. no. 1992-PS-8 (Pl. 1, fig. 8)

DGU Cat. no. 1992-PS-9 (Pl. 1, fig. 9)

DGU Cat. no. 1992-PS-12 (Pl. 2., fig. 3)

Stratigraphic occurrence. ME-6: 2082.1m - 2083.6m, MFA-4: 2403', MFB-7: 2264.7m - 2310.1m, M-1x: 1837.7m, M-9x: 1973.3m 2004.4m, M-10x: 1950.7 - 2001.0m. Latest Maastrichtian to Early Danian in the Dan Field, Danish North Sea.

Description. Camocavate cyst. The periphragm and endophragm are subspherical; the periphragm is appressed to the endophragm on the dorsal hemisphere. Ventrally a pericoel separates the periphragm from the endophragm. The pericoel communicates to the exterior through a subcircular claustrum in the periphragm. The claustrum occupies a midventral position and is approximately equal in size to the radius of the endophragm. The periphragm is smooth. Bi- and trifurcating processes with bifid terminations are present on the periphragm; their paratabular position was not determined. In areas where peri- and endophragm are separated, the length of the process stems is inversely proportional to the distance between the peri- and endophragm (Pl. 1, fig. 9; Pl. 2, figs 2, 3). The periphragm is smooth. The endophragm is granulate, verrucate or vermiculate (height of orna-mentation: $0.5-1.5 \mu \mathrm{m}$ ). The size and type of the ornament are constant within a sample, but vary from one group of samples to another. The archaeopyle type is $P(3)$ and the operculum is free. The paracingulum is often indicated by equatorial folds on the periphragm and by the presence of low septa between the longer processes. A parasulsus was not observed. Apart from paracingulum and archaeopyle the paratabulation is not clearly expressed.

Dimensions (in $\mu \mathrm{m}$ ): holotype range and mean $\begin{array}{lll}\text { overall length of pericyst } & 73 & 64(74) 84\end{array}$

$\begin{array}{lll}\text { overall width of pericyst (lat.) } & 81 & 70(78) 87\end{array}$

$\begin{array}{lll}\text { length of endocyst } & 44 & 36(40) 46\end{array}$

width of endocyst $\quad 38 \quad 32(38) 44$

length of processes 4 4-14 4 -20

Specimens measured. 12

Remarks. Hystrichostrogylon borisii sp. nov. differs from
Hystrichostrogylon coninckii Heilmann-Clausen 1985 in having a conspicuously ornamented endophragm. Together with $H$. coninckii, $H$. borisii sp. nov. differs from all other species of Hystrichostrogylon in having a large rounded midventral claustrum in the periphragm.

\section{Genus Isabelidinium Lentin and Williams 1977 Isabelidinium majae sp. nov.}

(Pl. 1, figs 1-6, text-fig. 4)

Derivation of name: Named after my daughter Maja. Diagnosis. A cavate peridinioid cyst with a smooth endoand periphragm without indications of paracingulum. The ambitus shows overall axial symmetry. The periarcheopyle is lati-deltaform.

Holotype. DGU Cat. no. 1992-PS-1 (Pl. 1, fig. 1, text-fig. 4a). Well M-10x, depth 1973.0m, Dan Field, Danish North Sea. Paratypes DGU Cat. no. 1992-PS-2 (Pl. 1, fig. 2, text Fig 4d) DGU Cat. no. 1992-PS-3 (PI. 1, fig. 3, text Fig 4f) DGU Cat. no. 1992-PS-4 (Pl. 1, fig. 4, text Fig 4c) DGU Cat. no. 1992-PS-5 (Pl. 1, fig. 5, text Fig 4e) DGU Cat. no. 1992-PS-6 (Pl. 1, fig. 6, text Fig 4g)

Stratigraphic occurrence. ME-6: 2082.1m - 2083.6m, MFB-7: 2283.0m - 2283.6m, M-10x: 1973.0m. Latest Maastrichtian in the Dan Field, Danish North Sea. Common in a narrow stratigraphic interval.

Description. Cavate peridinioid cyst. Cyst outline is almost bilateral symmetric in ambital view. The periphragm is smooth and has a broad-based rounded to acute apical horn and two acute to broad rounded antapical horns. The epicyst lacks shoulders, and has a concave margin. The area between the antapical horns has a moderately concave curvature. The endophragm is smooth and subcircular to oval in ambital view. The peri- and endophragm are often in contact laterally. The archaeopyle type is $\mathrm{I}(2)$ and is latideltaform with Transversal Archaeopyle Index (TAI) c. 0.70 . The paracingulum is not indicated. The parasulcus is often indicated by a longitudal fold in the periphragm. Apart from the archaeopyle and the parasulcus no other paratabulation is present.

Dimensions (in $\mu \mathrm{m}$ ): holotype range

$\begin{array}{lllll}\text { length of pericyst } & 96 & 87 & \text { (95) } 104\end{array}$

$\begin{array}{lllll}\text { width of pericyst } & 61 & 55 & \text { (61) } & 73\end{array}$

$\begin{array}{lllll}\text { length of endophragm } & 55 & 55 & \text { (58) } & 61\end{array}$

$\begin{array}{llll}\text { width of endophragm } & 55 & 52 & \text { (58) } 64\end{array}$

Specimens measured. 12

\section{Explanation of Plate 5}

Dinoflagellate cysts from the Dan Field, Danish North Sea. Scale bars $=20 \mu \mathrm{m}$.

Fig. 1 Spiniferites foveolatus sp. nov. DGU Cat. no. 1992-PS-39. Paratype. Lateral view, high focus. Fig. 2 Spiniferites foveolatus sp. nov. DGU Cat. no. 1992-PS-40. Holotype. Dorsolateral view, high focus. Same scale as 1. Fig. 3 Spiniferites foveolatus sp. nov. DGU Cat. no. 1992-PS-41. Lateral view, high focus. Same scale as 1. Fig. 4 Spiniferites foveolatus sp. nov. DGU Cat. no. 1992-PS-42. Lateral view, low focus. Same scale as 1. Fig. 5 Spiniferites foveolatus sp. nov. DGU Cat. no. 1992-PS-43. Paratype. Dorsolateral view, high focus. Same scale as 1. Fig. 6 Spiniferites foveolatus sp. nov. DGU Cat. no. 1992-PS-44. Paratype. Dorsal surface up, high focus. Same scale as 1. Fig. 7 Chlamydophorella? multifibrata sp. nov. DGU Cat. no. 1992-PS-45. Paratype. Unknown orientation. Fig. 8 Chlamydophorella? multifibrata sp. nov. DGU Cat. no. 1992-PS-46. Paratype. Lateral view, sectional focus. Same scale as 7. Fig. 9 Chlamydophorella? multifibrata sp. nov. DGU Cat. no. 1992-PS-47. Holotype. Apical view, high focus. Same scale as 7. Fig. 10 Chlamydophorella? multifibrata sp. nov. DGU Cat. no. 1992-PS-48. Paratype. Lateral view, sectional focus. Same scale as 7. Fig. 11 Chlamydophorella? multifibrata sp. nov. DGU Cat. no. 1992-PS-49. Lateral view, sectional focus. Same scale as 7. Fig. 12 Chlamydophorella? multifibrata sp. nov. DGU Cat. no. 1992-PS-50. Paratype. Ventral surface up, high focus. Same scale as 7. 

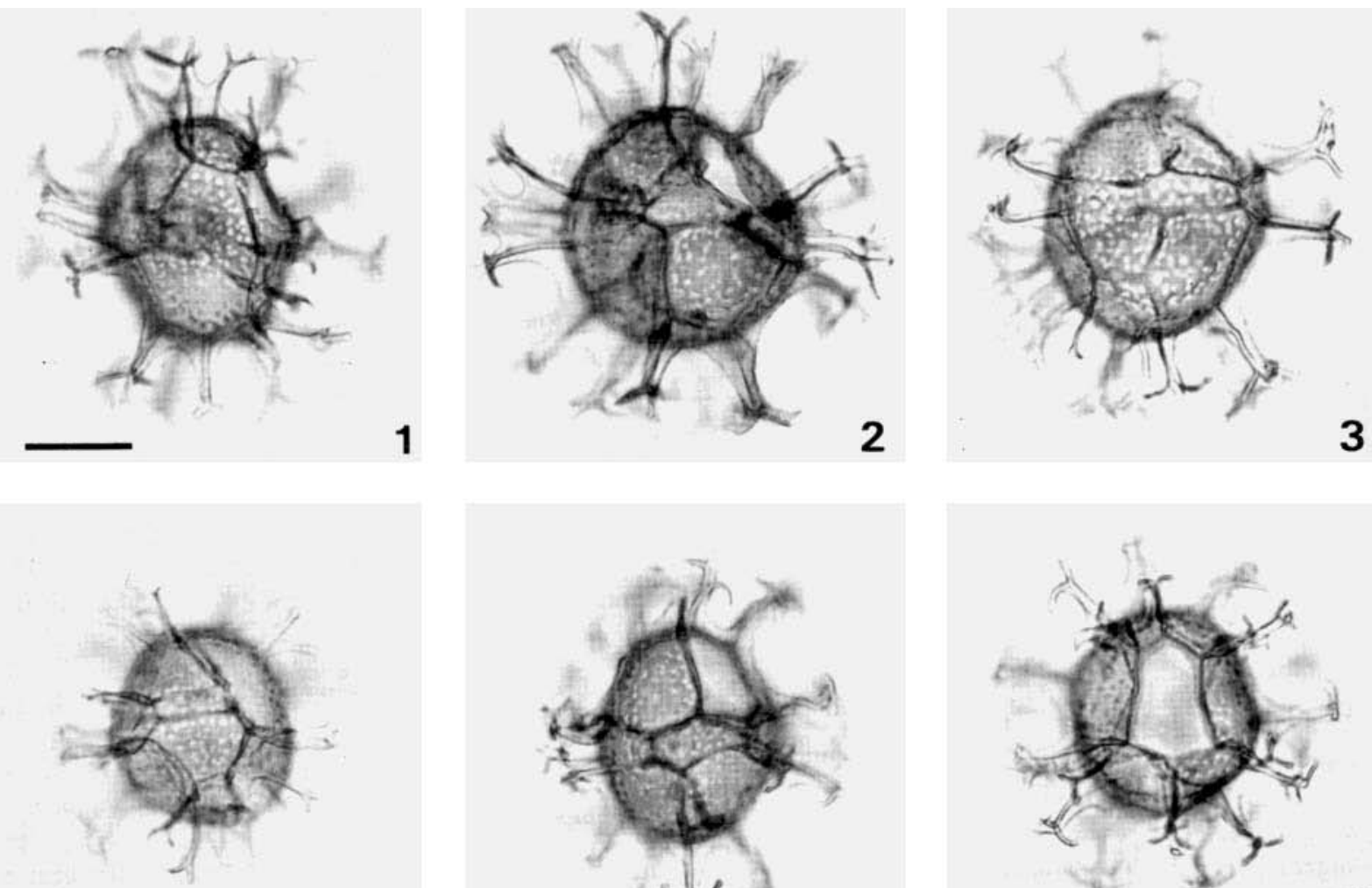

4
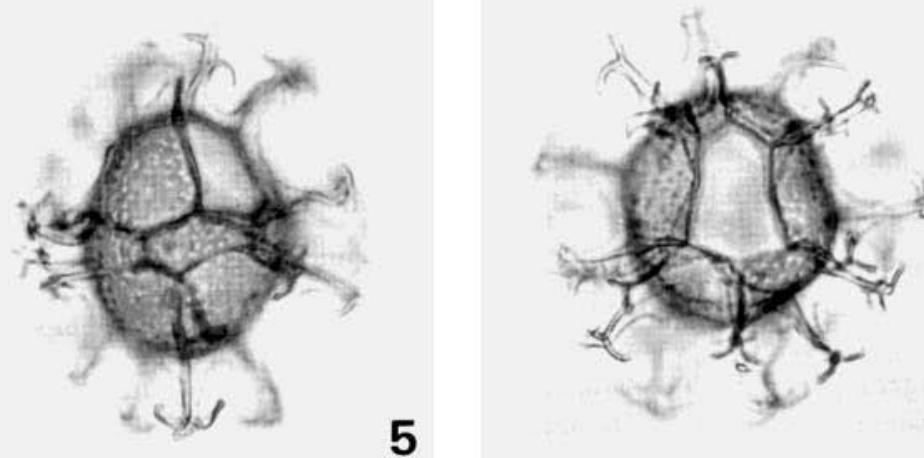

5

6

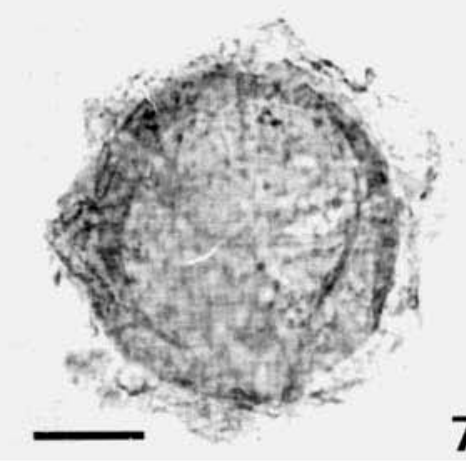

7

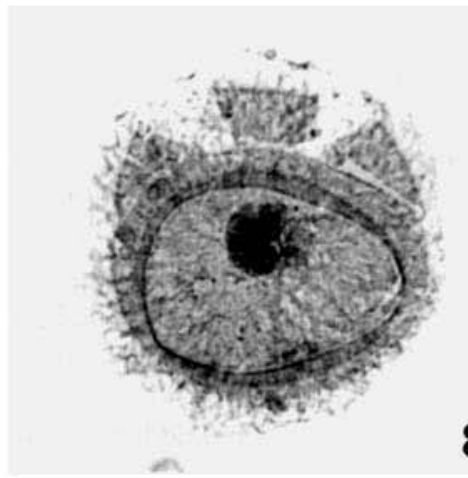

8

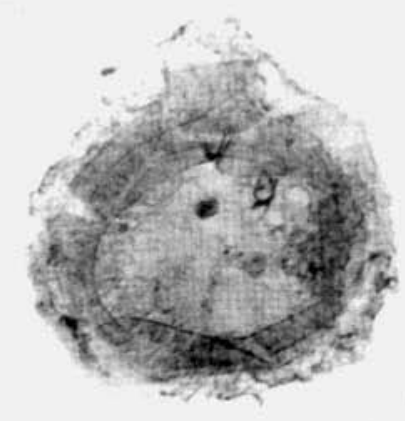

9
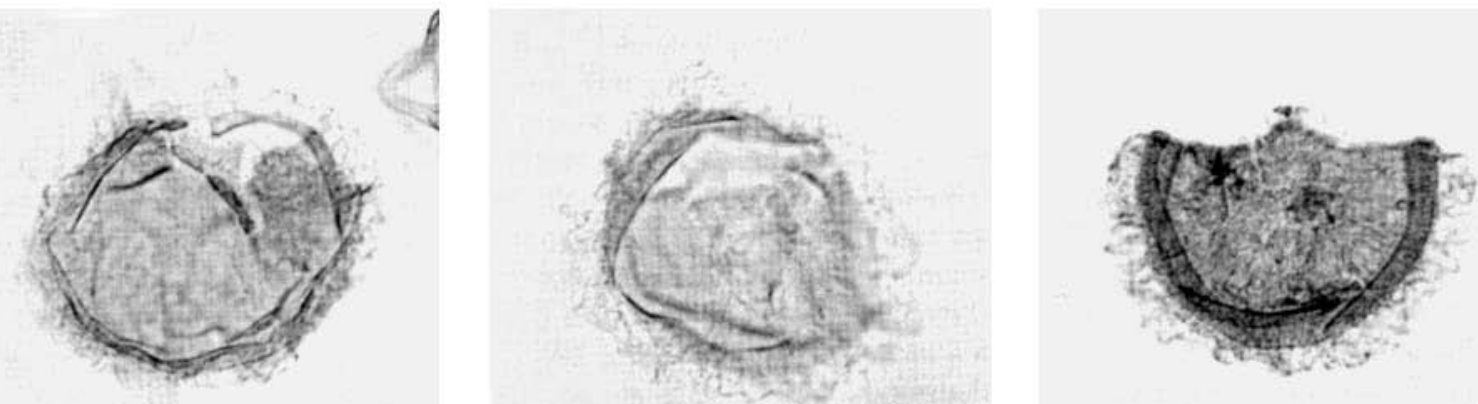

10 


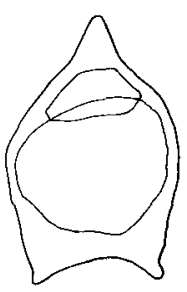

a

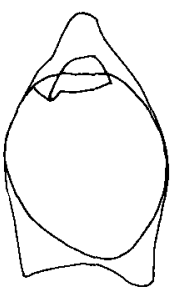

e

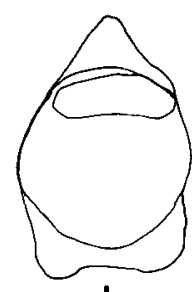

b

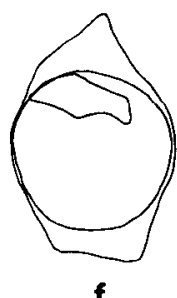

f

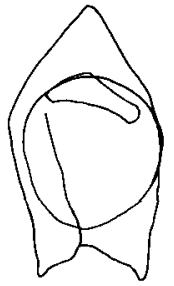

c

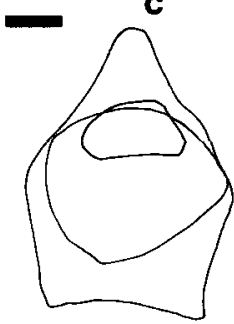

g

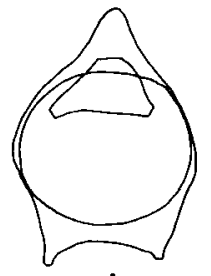

d

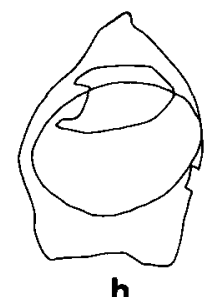

h
Fig. 4 Isabelidinium majae sp. nov. Outline tracings of specimens in ambital view. a) DGU Cat. no. 1992-PS-1, holotype. b) DGU Cat. no. 1992-PS4, paratype. c) DGU Cat. no. 1992-PS-51. d) DGU Cat. no. 1992-PS-2, paratype. e) DGU Cat. no. 1992-PS-5, paratype. f) DGU Cat. no. 1992PS-3, paratype. g) DGU Cat. no. 1992-PS-6, paratype. h) DGU Cat. no. 1992-PS-52. Scale bar $=20 \mu \mathrm{m}$.

Remarks. Isabelidinium majae sp. nov. differs from all other species of Isabelidinium by being almost axially symmetrical and having a lati-deltaform periarchaeopyle with a TAI considerably higher than 0.5 . These characters are typical of the genus Deflandrea Eisenack 1938 emend. Lentin and Williams 1978, but as the new species lacks any signs of a paracingulum, referral to the latter genus is precluded. Isabelidinium cooksoniae (Alberti 1959) Lentin and Williams 1977 differs from the new species in having shoulders or at least a convex epicystal outline, a reduced right antapical horn, and a thetaform to omegaform archaeopyle. Isabelidinium glabrum (Cookson and Eisenack 1969) Lentin and Williams 1977 differs in having an almost biconical ambitus, and a TAI around 0.46 as well as a reduced right antapical horn. Isabelidinium bakeri (Deflandre and Cookson 1955) Lentin \& Williams 1977 lacks a pronounced left antapical horn, but differs from 1 . majae sp. nov. in being widely fusiform, and having a narrow archaeopyle with a TAI around 0.44. Isabelidinium pelucidum (Deflandre and Cookson 1955) Lentin and Williams 1977 has an elongate ovale ambitus and a distinct hexagonal archaeopyle. Isabelidinium belfastense (Cookson \& Eisenack 1961) Lentin \& Williams 1977 and Isabelidinium greenense Marshall 1990 differs from the new species in archaeopyle-shape and in having antapical horns of different size. I. belfastense furthermore differs in having distinct apical and antapical granulation on the pericyst, and 1 . greenense has abundant fine perforations surrounding the horns. Manumiella? cretacea (Cookson 1956) Bujak \& Davies 1983 is smaller than I. majae sp. nov. and has an almost circular ambitus and a TAI around 0.38 . Camera lucida tracings of the ambital outline of the new species are shown in text-fig. 4 .

\section{Genus Leberidocysta Stover and Evitt 1978 Leberidocysta? flagellichnia sp. nov.} (P1. 3,figs 7-14, text-fig. 5)

Derivation of name. After the flagellar scar on the endophragm.

Diagnosis. A small holocavate oval cyst with a narrow pericoel. The periphragm is smooth, and occasionally has folds which indicate parts of the paratabulation. The endophragm is granulate and has a small, kidney-shaped scar in the sulcal area. The archaeopyle is apical and the opercula are usually attached.

Holotype. DGU Cat. no. 1992-PS-23 (Pl. 3, figs 7,8, text-fig. 5). Well M-9X, depth 2004.4m, Dan Field, Danish North Sea. Paratypes.

DGU Cat. no. 1992-PS-24 (Pl. 3, figs 9,10)

DGU Cat. no. 1992-PS-25 (Pl. 3, fig. 11)

DGU Cat. no. 1992-PS-26 (Pl. 3, fig. 12)

DGU Cat. no. 1992-PS-27 (Pl. 3, figs 13,14)

Stratigraphic occurrence. ME-6: 2082.1m - 2083.6m, MFA-4: 2403.1m - 2414.7m, MFB-7: 2281.5m - 2436.9m, M-1x: 1846.5m - 2003.8m, M-9x: 1979.4m - 2060.8m, M-10x: $1964.8 \mathrm{~m}$ - 2032.4m. Maastrichtian to Early Danian in the Dan Field, Danish North Sea; common.

Description. Oval holocavate cyst. The periphragm is thin and smooth, and is separated from the endophragm by a narrow $(1-3 \mu \mathrm{m})$ pericoel (Pl. 3, figs $8,10,13)$. The endophragm is relatively thick-walled and granulate to vermiculate. A conspicuous kidney-shaped ornament with low relief is always present ventrally on the endophragm beneath the point of operculum attachment (Pl. 3, figs 7,9,12,13,14, Text-fig 5). Archaeopyle apical (tA). The periand endoperculum usually are attached. The paracingulum is occasionally indicated by folds in the periphragm (Pl. 3, figs 11, 12). The position of the parasulcus is indicated by a kidney-shaped ornament on the endophragm, and sometimes by a longitudinal fold in the periphragm (Pl.3, fig. 12). The larger adcingular paraplates occasionally are indicated by folds in the periphragm (Pl. 3, fig. 12). The paratabulation occurs inconsistently and has not been determined.

\begin{tabular}{ccc} 
Dimensions (in $\mu \mathrm{m}):$ & holotype & \multicolumn{2}{c}{ range } \\
length of pericyst & 35 & $28(35) 41$ \\
width of pericyst & 36 & $32(36) 41$ \\
length of endocyst & 32 & $27(32) 36$ \\
width of endocyst & 33 & 30 (33) 38
\end{tabular}

\section{Specimens measured. 12}

Remarks. Form X spp. 1 and 2 of Marheinecke (1992, p. 121, pl. 27, figs 11-13, 7-9) closely resemble the new species in general appearance and size; Form $X$ sp. 2 apparently only differs from Leberidocysta? flagellichnia sp. nov. in having a larger antapical pericoel, and may be conspecific with the new species. Form $X$ sp. 1 differs further in having an alveolate endophragm. "Hexagonifera verrucosa" of Wilson (1974) differs from Leberidocysta? flagellichnia sp. nov. in having a verrucate endophragm (and thereby resembling Form X sp. 1 of Marheinecke, 1992). The kidney-shaped sulcal ornament is interpreted as representing the relict of 


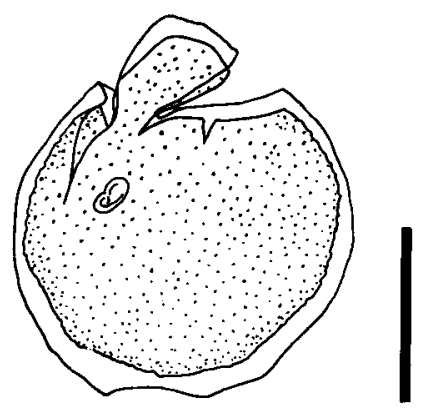

Fig. 5 Leberidocysta? flagellichnia sp. nov. DGU Cat. no. 1992-PS-23. Camera lucida drawing of the ventral surface of the holotype. Scale bar $=20 \mu \mathrm{m}$.

the flagella insertion point by the present author. It is with some hesitation that the new species is located in genus Leberidocysta as this genus is not thought to have attached opercula (Stover and Evitt, 1978 p. 60). However, the illustration of the type specimen of the genus, L. chlamydata, shows peri- and endoperculum in place (Cookson and Eisenack, 1962, Pl. 7, fig. 2). This fact is considered here to justify the generic location of the new species in Leberidocysta.

Genus Spiniferites Mantell 1850 emend. Sarjeant 1970 Spiniferites foveolatus sp. nov.

Pl. 5, Figs 1-6

Derivation of name. Named after its foveolate endophragm.

Diagnosis. A skolochorate gonyaulacoid cyst in which the endo- and periphragm are appressed between the processes. The processes occupy gonal positions and terminate trifurcate and bifurcate. Low to intermediate septal crests connect the processes. The periphragm is smooth, the endophragm is foveolate; the foveolation descends approximately half-way down the endophragm. Holotype. DGU Catalogue no. 1992-PS-40 (Pl. 5, fig. 2) Well M-9x, depth 2055.0m, Dan Field, Danish North Sea.

Paratypes.

DGU Cat. no. 1992-PS-39 (Pl. 5, fig. 1)

DGU Cat. no. 1992-PS-43 (Pl. 5, fig. 5)

DGU Cat. no. 1992-PS-44 (Pl. 5, fig. 6)

Stratigraphic occurrence. MFA-4: 2404.9m - 2411.0m, MFB7: 2297.0m - 2433.5m, M-1x: 1846.5m - 1917.5m, M-9x: 2001.6m - 2060.7m, M-10x: 1964.8m - 2029.4m. Late Maastrichtian in the Dan Field, Danish North Sea. Common.

Description. A skolochorate gonyaulacoid cyst with gonal processes. The endo- and periphragm are appressed between processes. The processes are solid with distal biand trifurcations, and are proximally connected by septal crests of low to intermediate height. The periphragm is entire and smooth. The endophragm is thicker than the periphragm and ornamented with circular to vermiculate pits and foveolae, descending approximately half way through the phragm. The dimension of the ornament is $1-2$ $\mu \mathrm{m}$. The ornament generally occupies a penitabular position on the paraplates. The number of foveolae and pits in the larger paraplates is $20-40$. Paratabulation and archaeopyle type as for the genus.

$\begin{array}{lcc}\text { Dimensions (in } \mu \mathrm{m} \text { ): } & \text { holotype } & \text { range } \\ \text { Overall length of pericyst } & 81 & 70(77) 84 \\ \text { Overall width of pericyst } & 73 & 61(72) 81 \\ \text { length of endocyst } & 44 & 40(44) 49 \\ \text { width of endocyst } & 41 & 35(41) 52\end{array}$

Specimens measured: 10

Remarks. The new species is distinguished from all other species of Spiniferites by its foveolate endophragm. Spiniferites ramosus endoperforatus (Corradini 1973) Lentin and Williams 1975 has a perforate endophragm with perforations much smaller than the foveolation of the new species, judging from the illustrations of Corradini's holotype. Due to its generally penitabular arangement, its restriction to the endophragm, and its consistent occurrence within a population, the ornament is not considered a preservational artefact, but an original morphological feature.

\section{Spiniferites pseudofurcatus (Klumpp 1953) Sarjeant 1970 emend. Sarjeant 1981 \\ Spiniferites pseudofurcatus granulosus ssp. nov.} (Pl. 4, figs 1-3)

Derivation of name. After the ornament on the endophragm.

Diagnosis. A skolochorate gonyaulacoid cyst in which the endo- and periphragm are appressed between the processes. The processes occupy gonal positions and terminate bifurcate to tetrafurcate and never ramify. Low septal crests connect the processes. The periphragm is slightly striate, the endophragm is finely granulate.

Holotype. DGU Catalogue no. 1992-PS-29 (Pl. 4, fig. 2) Well M-9x, depth 2031.2m, Dan Field, Danish North Sea.

Paratypes. DGU Cat. no. 1992-PS-28 (Pl. 4, fig. 1)

DGU Cat. no. 1992-PS-30 (Pl. 4, fig. 3)

Stratigraphic occurrence. ME-6: 2082.1m - 2083.6m, MFA-4: 2403.1m - 2408.9m, MFB-7: 2297.0m - 2367.7m, M-1x: 1854.4m - 1997.7m, M-9x: 2004.4m - 2055.0m, M-10x: $1969.0 \mathrm{~m}$ - 2029.4m. Maastrichtian in the Dan Field, Danish North Sea. Rare to frequent.

Remarks. The new subspecies differs from the two other subspecies of Spiniferites pseudofurcatus only in having a granulate endophragm and a slightly striate periphragm.

\section{DINOFLAGELLATE STRATIGRAPHY}

The stratigraphic distribution of the new taxa is summarised in Fig. 6 . The restricted stratigraphic occurrence of Isabelidinium majae $\mathrm{sp}$. nov. and Hystrichosphaeropsis perforata sp. nov. suggests that they are important marker species for narrow stratigraphic intervals in the Late Maastrichtian. The first appearance datum of Hystrichostrogylon borisii sp. nov. is considered an important stratigraphic marker for the latest Maastrichtian (Schiøler 
and Wilson; 1992, 1993). The last occurrence datum of Achomosphaera antleriformis sp. nov., Cassiculosphaeridia? tocheri sp. nov., Spiniferites foveolatus sp. nov. and Spiniferites pseudofurcatus granulosus ssp. nov. marks the transition from the Maastrichtian to the Danian in the area.

\section{ACKNOWLEDGEMENTS}

The Danish Research Academy is acknowledged for support during a research fellowship, supervised by F. Surlyk, University of Copenhagen. The Danish ministry of Energy and Maersk Olie og Gas AS are acknowledged for supporting the Dan Field Project at the Geological Survey of Denmark, of which the present study forms a part. Graeme J. Wilson, Institute of Geological and Nuclear Sciences 1td, Lower Hutt, New Zealand, is thanked for helpful suggestions and for critically reading the manuscript. Constructive criticism by an anonymous journal referee is gratefully acknowledged.

\section{REFERENCES}

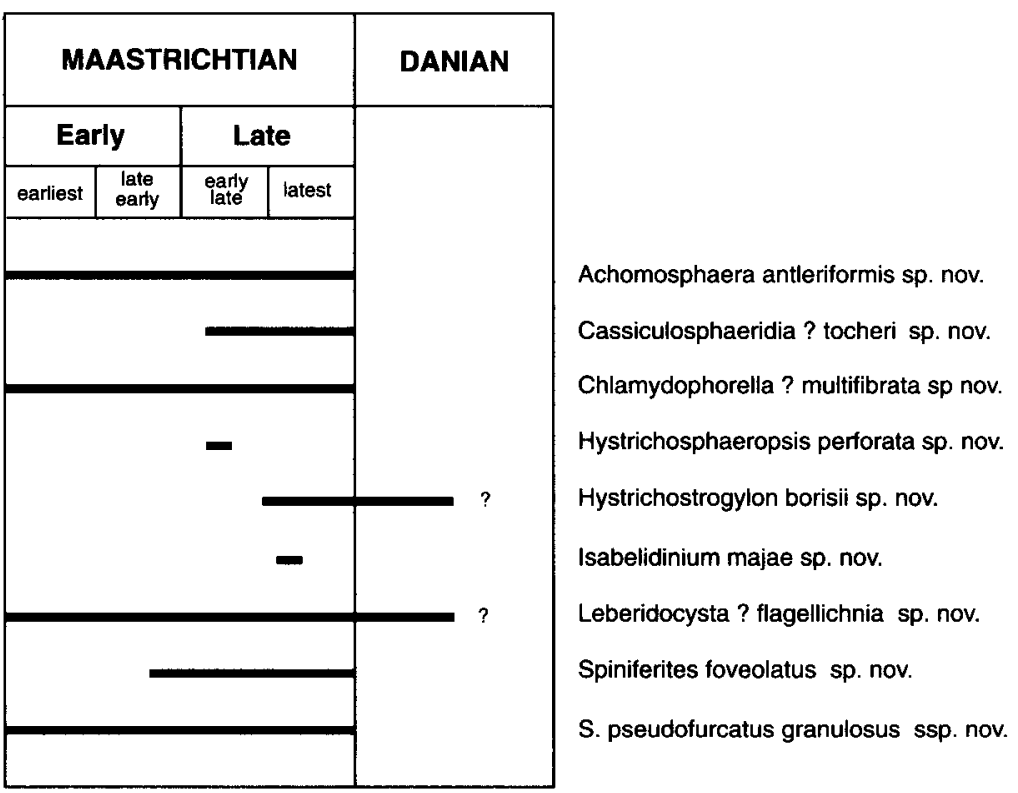

Andersen, C. and Doyle, C., 1990. Review of hydrocarbon exploration and production in Denmark. First Break, 8(5), 155165.

Bagnall, J. M., Church, J. W., Haskins, C. W., 1971. The micropalaeontology and stratigraphy of the interval 5400'7574' of the Gulf Dansk Nordso M-IX well. Robertson Research Company Limited, $15 \mathrm{pp}$. (unpublished, available at the Geological Survey of Denmark, Archive/Core Store).

Bailey, H. W., 1980. Well M-9x stratigraphical/palaeontological final report. Paleo Services Btd, 30 pp.(unpublished, available at the Geological Survey of Denmark, Archive/Core Store).

Bailey, H. W., 1983. Well M-IOX (6420'6530') palaeontological/ stratigraphical analysis of selected core samples. Paleo Services Ltd, 6 pp. (unpublished, available at the Geological Survey of Denmark, Archive/Core Store).

Bailey, H. W., and Jutson, D., 1983. Well M-lOx paleontological/ stratigraphical analysis of selected core samples (interval 6,334'8"$6340^{\prime 2}{ }^{\prime \prime}$. Paleo Services Ltd., 8 pp. (unpublished, available at the Geological Survey of Denmark, Archive/Core Store).

Charnock, M. A, Church, J. V. and Merker, A. M., 1985. Maersk MFA-4, MFA-ll. M-9X and M-lOX Wells; Dan Field, offshore Denmark: Biostratigraphy of selected core pieces. Robertson Research International Limited, $23 \mathrm{pp}$. (unpublished, available at the Geological Survey of Denmark, Archive / Core Store).

Cookson, I. C. and Eisenack, A., 1962. Additional microplankton from Australian Cretaceous sediments. Micropaleontology, 8(4), 485-507.

Deegan, C. E. and Scull, B. J., 1977. A proposed Standard Lithostratigraphic Nomenclature for the Central and Northern North Sea. Rep. Inst. Geol. Sci., 77/25, 36 pp.

Hansen, J. M., 1977. Dinoflagellate stratigraphy and echinoid distribution in Upper Maastrichtian and Danian deposits from Denmark. Bull. Geol. Soc. Den., 26, 1-26.

Jorgensen, L. N., 1993. The Dan Field. In E. Beaumont and N. Foster (Eds), AAPG Treatise of Petroleum Geology, atlas of oil and gas fields. Structural traps IV, 199-218.

Kirsch, K.-H., 1991. Dinoflagellatenzysten aus der Oberkreide des Helvetikums und Nordultrahelvetikums von Oberbayern. Munchner Geowiss. Abh. (A), 22, 306 pp.

Koch, W., 1977. Biostratigraphie in der Oberkreide und Taxonomie von Foraminiferen. Geol. Jahrb., 38, 11-123. 